\title{
The Myth of Disease and Acid/Alkaline food on Blood Acidity Balance
}

Amal Alsalem, School of Nutrition and Dietetics, Acadia University, Wolfville, NS

\section{Introduction}

- Healthy blood pH tightly range between 7.35 to 7.45 (Pizzorno etal. 2009)

- Buffer system is a solution that naturally resists a change in $\mathrm{pH}$ when acids or bases exist (Carnauba et al. 2017)

\section{Misleading information in nutrition}

\section{Controversy around Blood $\mathrm{pH}$ imbalance}

An urge

Need of education

\section{Objective}

- To explore the scientific evidence on the relationship between acid/alkaline food and blood $\mathrm{pH}$.

- This relationship can be easily misunderstood by the public because the maintenance of blood $\mathrm{pH}$ involves complicated and continuous chemistry processes.

\section{Method}

- 14 articles were reviewed as follows:

- 7 were peer-reviewed journals and 1 of them were recently published in 2017

- Gray literature

- PEN and Dietitian of Canada

- Google scholar \& PubMed

- Krause's nutrition textbook

- Using the key words: Blood pH, Alkaline diet, and blood acid- base balance

\section{Future Work \& Questions}

- If the fluctuation of the $\mathrm{pH}$ within the normal range may cause chronic disease over time, normal blood $\mathrm{pH}$ range must be changed. Further studies are needed to verify this claim

- Does acidosis and alkalosis affect normal aging process?

- Since breathing is essential for survival, so is acid-base balance why the latter burnout human body while breathing does is not?

\section{References:}

- Buclin, T., Cosma, M., Appenzeller, M., Jacquet, A.-F., Décosterd, L. A., Biollaz, J., \& Burckhardt, P. (2001). Diet Acids and Alkalis Influence Calcium Retention in Bone. Osteoporosis International, 12(6), 493-499. https://doi.org/10.1007/s001980170095. In: Practice-based Evidence in Nutrition [PEN].

- Carnauba, R. A., Baptistella, A. B., Paschoal, V., \& Hübscher, G. H. (2017). Diet-Induced LowGrade Metabolic Acidosis and Clinical Outcomes: A Review. Nutrients, 9(6).

ps: / / doi.org/10.3390/nu9060538

Frassetto, L., Morris, J. R., Sellmeyer, D. E., Todd, K., \& Sebastian, A. (2001). Diet, evolution, and aging. European Journal of Nutrition, 40(5), 200-213. doi:10.1007/s394-001-8347-4 Kellum, J. A. (2000). Determinants of blood pH in health and disease. Critical Care, 4, 6

Mahan, K., \& Raymond, J. (2017). Krause's Food \& the Nutrition Care Process 14ed. St. Louis Missouri: Elsevier.

Dietitians of Canada (n.d.) $P E N \circledast$ Editor's Pick: Does an alkaline diet have a role in the risk, prevention or treatment of chronic diseases. In: Practice-based Evidence in Nutrition [PEN] Available from

dence-in-Nutrition--PEN-/PEN-Editors-Pick-Alkaline-Diet-and-chronic-disease.aspx.

Acsessed March 12, 2017. Access only by subscription.

Pizzorno, J., Frassetto, L. A., \& Katzinger, J. (2009). Diet-induced acidosis: is it real and clinically relevant? British Journal of Nutrition, 1. doi:10.1017/s0007114509993047

Schwalfenberg, G. K. (2012). The Alkaline Diet: Is There Evidence That an Alkaline pH Diet Benefits Health? Journal of Environmental and Public Health, 2012.

\section{Results}

1. Three main systems maintain blood $\mathrm{pH}$ balance hemostasis strictly:

- Respiratory

- Renal

- Buffers (Kellum. (2000).

2. Two main components found inside human blood :

- Main acid $\left(\mathrm{CO}_{2}\right)$

- Base $\left(\mathrm{HCO}_{3}\right)$ called bicarbonate (Mahan \& Raymond. (2017)

3. Arterial Blood gas (ABG) test and blood serum electrolyte values are the only ways to evaluate blood pH status (Mahan \& Raymond. (2017)

4. All sources agreed that:

- Any tiniest fluctuation in blood $\mathrm{pH}$ above or below the normal level leads to serious health complications or even death

- Did not support the claim that food intake impact blood $\mathrm{pH}$ in healthy population

5. Food impacts Urine $\mathrm{pH}$, acid or alkaline, but not blood $\mathrm{pH}$ to maintain internal blood environment balance (Carnauba et al. 2017)

6. Some researchers found that maintaining blood $\mathrm{pH}$ on the extreme sides of the normal range 7.35 to 7.45 may results in health problem on the long run (Pizzorno etal. 2009)

7. Inconsistent results and lack of evidence between protein intake and bone health (PEN Diet Composition. 2016)

8. Meat, eggs, cheese and grains produce acids metabolite where fruits and vegetables produce base metabolite (Scialla \& Anderson. (2013)

\section{Conclusion}

- From reviewing data it appears that although acid/ alkaline food may increase the acid load and consequently the net acid excretion through the kidneys, there has not been a clear evidence connecting extreme normal levels of blood $\mathrm{pH}$ and long term chronic disease in healthy

- There is no strong evidence that acid alkaline food directly affects blood $\mathrm{pH}$

\section{Significance to the field of dietetics}

- Dietitians need to convey the true science about blood $\mathrm{pH}$ and food intake in an understandable way to the public

- Increase awareness to question anyone, regardless of their scientific background who promotes this myth

- The developed Algorithm and other methods may be used as a tool for dietitian to promote vegetables and fruits eating, which in return will increase health (Frassetto et al. 2001)

Acknowledgement

Dr. Catherine Morley who supervised me for this work last year

Scan to contact me@ linkedin \& my profile name is : Hope and Pe 